\title{
The selective functionalisation of saturated hydrocarbons: Gif and all that
}

\author{
Derek H. R. Barton and Darío Doller \\ Department of Chemistry, Texas A and M University, College Station, TX 77843, USA
}

\begin{abstract}
The Gif family of systems for the selective oxidation of saturated hydrocarbons are briefly described. The mechanism of the reaction is analysed in terms of four intermediates. The first is well characterised as an $\mathrm{V}_{\mathrm{Fe}} \sigma$-carbon bond species and the last has been fully identified, at least in the case of cyclohexane, as a hydroperoxide. The utility of dynamic ${ }^{13} \mathrm{C}$ NMR spectroscopy in iron containing systems is demonstrated. Gif type chemistry is closely related to the unusual enzyme methane monooxygenase.
\end{abstract}

\section{PART I. DEREK H. R. BARTON}

The invention of chemical reactions which will selectively functionalise saturated hydrocarbons under mild conditions (for example at room temperature and at neutral $\mathrm{pH}$ ) represents a noble challenge for the chemists working in the last two decades of this century ${ }^{1}$. Already the porphyrin based iron containing enzymes, such as the $P_{450}$ enzymes, have received much attention ${ }^{2}$. Their reactivity, at least in model systems, is radical like and considered to involve an $\mathrm{Fe}^{\mathrm{IV}}$ oxenoid species liganded to a porphyrin radical cation. From the practical point of view the most promising reaction is the epoxidation of olefins by model systems ${ }^{3}$. A long known reaction which satisfies in part our definition is the Fenton hydrogen peroxide $\mathrm{Fe}^{\mathrm{II}}$ oxidation system ${ }^{4}$. However, this generates hydroxyl radicals, which are very reactive and thus unselective.

When we began to study the selective oxidation of saturated hydrocarbons in 1980 , we were aware of a short communication from the late Prof. Tabushi ${ }^{5 a}$, who was attempting a biomimetic type oxidation of adamantane 1. In order to solubilise this hydrocarbon he used pyridine. Oxidation with oxygen, a thiol and an $\mathrm{Fe}^{\mathrm{II}}$ salt, considered a surrogate for a $\mathrm{P}_{450}$ enzyme, gave, like other such models, very little oxidation. However, the selectivity observed was unusual, since there was more secondary than tertiary substitution. Much radical chemistry by Tabushi and others has shown that adamantane ${ }^{5 b}$, as expected, is substituted mainly at the tertiary position. We repeated and confirmed these experiments and modified the system. There was little oxidation, but the selectivity continued to be unusual.

Life existed on Earth under anaerobic conditions long before the blue-green algae started to make oxygen. Under reducing conditions the atmosphere was full of hydrocarbons, especially methane; there was much hydrogen sulfide, from reduction of sulfate; the abundant element iron was present as metallic iron (cf. bog iron) and in the seas as $\mathrm{Fe}^{\mathrm{II}}$. A form of life took advantage of the new aerobic conditions to oxidise the iron to $\mathrm{Fe}^{\mathrm{III}}$ and deposit it as pure ferric oxide in vast mountain ranges in Australia and Brazil. It<smiles>[R]C1([R])C2CC3CC(C2)CC1C3</smiles>

1. $R^{1}=R^{2}=H$

2. $R^{1}, R^{2}=O$

seemed to me, on reflection, that the new form of life would have obtained far more energy from concerting the oxidation of iron and hydrocarbons together than from just making ferric oxide. The hydrocarbon oxidation products $\left(\mathrm{CO}_{2}\right)$ would have left no geological trace. 


\begin{tabular}{|c|c|c|c|c|c|c|}
\hline & & & & & & \\
\hline \multirow{5}{*}{$1.75 \mathrm{mmol}$} & $\underset{\text { (mmol) }}{\mathbf{X}}$ & $\Sigma(\%)$ & $\%$ & $\%$ & \% & $\%$ \\
\hline & 7.2 & 85 & 85 & 0 & 0 & 0 \\
\hline & 4.1 & 78 & 78 & 0 & 0 & 0 \\
\hline & 2.0 & 81 & 43 & 3 & 22 & 13 \\
\hline & 1.0 & 72 & 18 & 15 & 18 & 21 \\
\hline
\end{tabular}

Although this reasoning was naive, it led to a simple, but fundamentally important, experiment. To the adamantane in pyridine containing hydrogen sulfide I suggested that $\mathrm{Dr}$. Gastiger ${ }^{6}$ should add iron powder and an equivalent amount of acetic acid (to dissolve the iron) and stir the suspension under air. The iron powder, aided by a surface effect of the hydrogen sulfide, dissolved and the adamantane was oxidised to mainly adamantanone 2 with a 10-, then 20 - and finally 30 -fold increase in yield. The first significant Gif system (Gif III) had been invented. Later?, we showed that the reaction could be made catalytic in iron (up to 2,000 turnovers) by using metallic zinc as a source of electrons (Gif ${ }^{\mathrm{lV}}$ ). Hydrogen sulfide was not needed for $\mathrm{Gif}^{\mathrm{IV}}$, nor for $\mathrm{Gif}^{\mathrm{III}}$ if the temperature was raised to $30-40^{\circ} \mathrm{C}$ to start the reaction. From the beginning I did not think that carbon radicals could play a major role as they are quenched efficiently by the $-\mathrm{S}-\mathrm{H}$ bond. Some recent work carried out in association with Prof. G. Balavoine, Dr. A. Gref and Mlle. I. Lellouche (Table 1) has shown that when cyclohexyl radicals are generated in presence of hydrogen sulfide they are indeed efficiently quenched by hydrogen atom transfer.

Further work ${ }^{8}$ has shown that the various Gif systems (Table 2) are based on the reaction of superoxide with $\mathrm{Fe}^{\mathbb{I}}$ or of hydrogen peroxide with $\mathrm{Fe}^{\mathrm{III}}$ to afford an $\mathrm{Fe}^{\mathrm{V}}$ oxenoid species. The $\mathrm{Fe}^{\mathrm{V}}$ species is the same as in $\mathrm{P}_{450}$ models, but it is not reduced by electron transfer from the porphyrin ligand. It has, therefore, very different chemical reactivity.

Our nomenclature (Table 2) is based on Geography. Gif comes from Gif-sur-Ivette in France where the first experiments were carried out. GO is the electrochemical system, which was studied in collaboration with Prof. Balavoine at Orsay (Universite de Paris-Sud), hence Gif-Orsay. When we moved to Texas $\mathrm{A}$ and $\mathrm{M}$, in Aggieland, it was logical to add Agg giving us GoAggI, a theoretically important, but not practical system, as well as GoAgg ${ }^{I}$ and GoAgg ${ }^{\text {, }}$, where hydrogen peroxide is the oxidant for the iron and the systems are homogeneous. Professor Sawyer has recently introduced ${ }^{9}$ another, and potentially important, GoAgg system based on the reaction of oxygen with ferrous picolinate. Dr. Geletii has carried out important, pioneering work ${ }^{10}$ on an analogous $\mathrm{Cu}^{\mathrm{II}}$ system.

Table 2

\begin{tabular}{|c|c|c|}
\hline \multicolumn{3}{|c|}{$\begin{array}{l}\text { GIF SYSTEMS } \\
\text { Pyridine - Acetic Acid - Room Temperature }\end{array}$} \\
\hline $\begin{array}{l}\text { Gif III } \\
\text { Gif }^{\mathrm{IV}} \\
\text { GO } \\
\text { GoAggI }\end{array}$ & $\begin{array}{l}\mathrm{Fe}^{\mathrm{O}} \cdot \mathrm{O}_{2} \\
\mathrm{Fe}^{\mathrm{I}} \text { cat. }-\mathrm{Zn}^{0} \cdot \mathrm{O}_{2} \\
\mathrm{Fe}^{\mathrm{II}} \text { cat. }- \text { cathode } \cdot \mathrm{O}_{2} \\
\mathrm{Fe}^{\mathrm{I}} \cdot \mathrm{KO}_{2} \cdot \mathrm{Ar}\end{array}$ & $\mathrm{Fe}^{\mathrm{II}}$ \\
\hline $\begin{array}{l}\text { GoAgg II } \\
\text { GoAgg II }\end{array}$ & $\begin{aligned} & \mathrm{Fe}^{\mathrm{II}} \text { cat. }-\mathrm{H}_{2} \mathrm{O}_{2}-\mathrm{Ar} \\
= & \mathrm{GoAgg}{ }^{\prime}+\text { ligand }\end{aligned}$ & $\mathrm{Fe}^{\text {III }}$ \\
\hline
\end{tabular}

Table 3

\begin{tabular}{l} 
GIF CHEMISTRY $\quad$ KETONES \\
$\mathrm{CH}_{2} \longrightarrow \mathrm{CH}_{2} \longrightarrow \mathrm{O}$ sec. > tert. 2 prim. \\
\hline $\mathrm{CHX} \quad \mathrm{X}=\mathrm{SePh} ; \mathrm{SPh} ; \mathrm{Br}, \mathrm{Cl} ; \mathrm{S}_{n}$ \\
\hline
\end{tabular}


Our early work was carried out to give a maximum yield of ketone. Some earlier work on picolinic acid as a ligand ${ }^{11}$ had been carried out using $\mathrm{Fe}^{\mathrm{II}}$ and hydrogen peroxide, but did not give an improved yield of ketone. It was Professor Sawyer who informed me that picolinic acid as a ligand made the reaction more rapid ${ }^{12}$. We have examined a number of ligands ${ }^{13}$ and some of them, like picolinic acid or pyrazine-2-carboxylic acid make the oxidation fifty times faster. Others, like pyridine-2-phosphonic acid, stop the reaction dead. So far changing ligands has only increased the speed of the oxidation, but has not increased the yield. Clearly, the synthesis of modified ligands is an important new objective for Gif chemistry.

In Table 3 we present a brief summary of the chemical reactivity of the Gif systems. The selective oxidation of saturated hydrocarbons to ketones is the most striking reaction and up to a reasonable conversion the reaction is quantitative. The capture of an intermediate (Table 3 ) is discussed in more detail later.

A new development ${ }^{14}$, related to the biosynthesis of penicillin and biotin, is the demonstration that Gif type chemistry in the presence of $\mathrm{H}_{2} \mathrm{~S}, \mathrm{H}_{2} \mathrm{~S}-\mathrm{S}$ or $\mathrm{Na}_{2} \mathrm{~S}$ affords both oxidation products and, especially with cyclohexane, di- and polysulfides. In the presence of picolinic acid the oxidation products are suppressed and only dicyclohexyl disulfide and related polysulfides are seen. Under GoAgg ${ }^{\text {III }}$ conditions the sulfation process is remarkably efficient and nearly half of the sulfur in the reagent ends up in the di- and poly-sulfides. The new oxygen-ferrous dipicolinate system of Professor Sawyer ${ }^{9}$ works using hydrogen sulfide (or other reducing agent) to reduce the $\mathrm{Fe}^{\mathrm{II}}$ formed back to $\mathrm{Fe}^{\mathrm{II}}$. If this is a Gif type system then the hydrogen sulfide present should also be making polysulfides. Recent work in collaboration with the group from Orsay (Table 4) has shown that this is indeed the case. The original work ${ }^{9}$ had overlooked the formation of this compounds.

Table 4

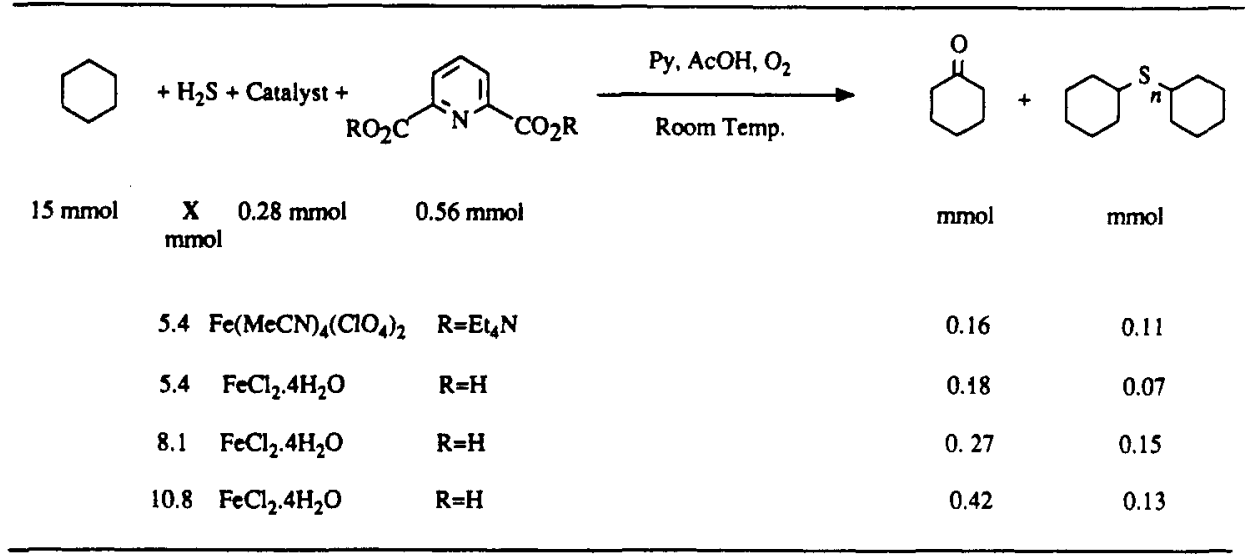

In our original studies of the oxidation of adamantane tert. radicals could be detected by competitive capture by pyridine and oxygen. A careful comparative study ${ }^{15}$ has confirmed that secondary radicals are not involved in Gif chemistry to any significant extent. Tert. radicals are not normally important; adamantane is a special case.

We have recently compared ${ }^{16}$ genuine radical bromination of saturated hydrocarbons using $\mathrm{BrCCl}_{3}$ with Gif type oxidative bromination in the presence of $\mathrm{BrCCl}_{3}$. By mixing pairs of hydrocarbons and running the reactions to $30 \%$ conversion, or more, a reliable quantitative rate order could be established. The results are summarised in Table 5. The radical bromination order is in agreement with limited literature data and presents no surprises. The GoAgg ${ }^{\text {II }}$ data are completely different. In the real radical reactions cyclohexane reacts more slowly than the other hydrocarbons. In GoAgg ${ }^{\text {II }}$ cyclohexane reacts faster than any other hydrocarbon examined. The data in Table 5 are normalised for the number of $\mathrm{C}-\mathrm{H}$ bonds. Another remarkable difference is that the radical reaction gives, as expected, $\mathrm{CHCl}_{3}$ (determined quantitatively by proton NMR), whilst the GoAgg ${ }^{\text {II }}$ reactions produce $\mathrm{CO}_{2}$ from the $\mathrm{BrCCl}_{3}$ (determined quantitatively as $\mathrm{BaCO}_{3}$ ). Clearly Gif chemistry and radical chemistry are very different and, therefore, demand different theoretical interpretations. 
Table 5

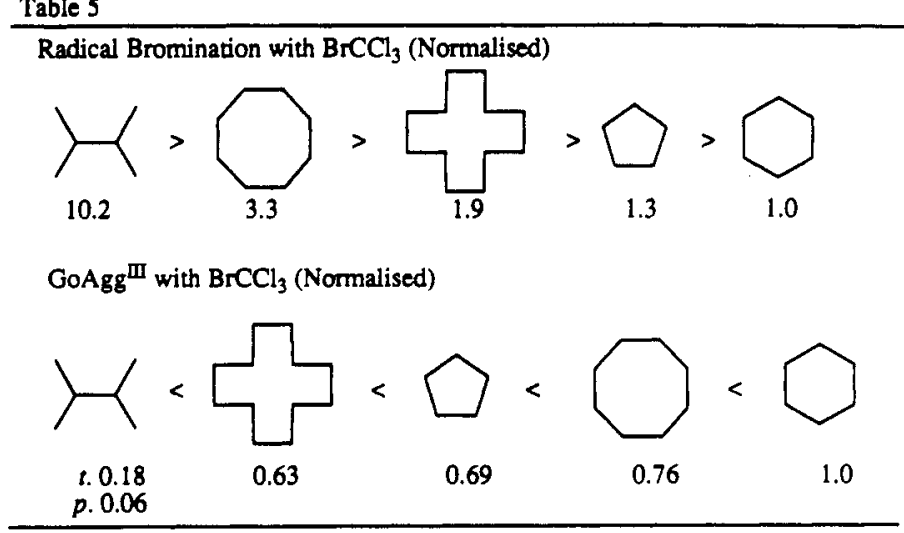

In Table 6 we have summarised many experimental facts. Gif chemistry produces ketones as major products. A lesser amount of the secondary alcohol is always formed. Ketone and secondary alcohol are not interconverted at a significant rate under the experimental conditions. The water content of the system has a definite effect ${ }^{17}$ on the ketone-alcohol ratio as shown in Table 7. A comparison of $\mathrm{Gif}^{\mathrm{V}}$ with GoAgg ${ }^{\mathrm{II}}$ shows clearly ${ }^{18}$ that the ketone-alcohol ratio is lower for the GoAgg II system, where the water content (from the $30 \%$ aqueous hydrogen peroxide) is higher.

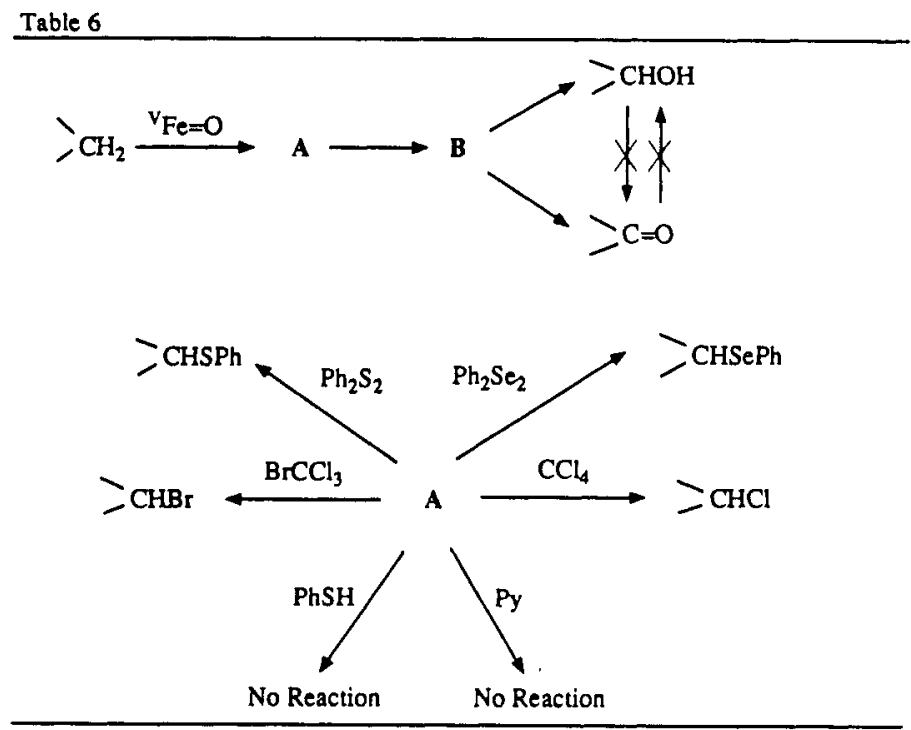

From all these facts two intermediates $\mathbf{A}$ and $\mathbf{B}$ were identified (Table 6). The first intermediate $\mathrm{A}$ is captured by $\mathrm{Ph}_{2} \mathrm{Se}_{2}$ and $\mathrm{BrCCl}_{3}$ quantitatively ${ }^{16,19}$. It is also captured by $\mathrm{Ph}_{2} \mathrm{~S}_{2}, \mathrm{CCl}_{4}$ and $\mathrm{CHBr}_{3}$. Normally these facts would suggest radical chemistry. However $\mathrm{A}$ is not captured by pyridine under conditions where real carbon radicals are easily detected ${ }^{15}$. Recently we have examined carefully ${ }^{18,20}$ the effect of thiophenol on the Gif ${ }^{\mathrm{VI}}$ system. Unless stated to the contrary, Gif ${ }^{\mathrm{V}}$ is Gif ${ }^{\mathrm{III}}+$ picolinic acid and $\mathrm{Gif}^{\mathrm{VI}}$ is $\mathrm{Gif}^{\mathrm{VV}}+$ picolinic acid. As shown in Table 8 one $\mathrm{mmol}$ of thiophenol has a major effect on the ketone-alcohol ratio, but has no significant effect on the total oxidation. The addition of more thiophenol reduces further the ketone-alcohol ratio without a major change in the amount of oxidation. Again, these observations are incompatible with a radical nature for intermediate A. Franz has recently shown ${ }^{21}$ that the rate constant for the quenching of a carbon radical with thiophenol is diffusion controlled. Thus the addition of thiophenol, if $\mathbf{A}$ were a radical, would afford a strong inhibition of oxidation. This is not the case. Similar results are seen when dianisyl telluride is added ${ }^{22}$. Again intermediate A cannot be a carbon radical, but the water effect and the effect of thiophenol and dianisyl telluride show that a second intermediate $B$ is needed. 


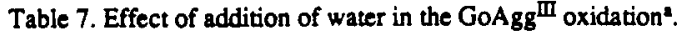

\begin{tabular}{lcc}
\hline $\mathrm{H}_{2} \mathrm{O}$ (mmol) & $\begin{array}{c}\text { Conversion, \% } \\
\text { (Ketone + Alcohol) }\end{array}$ & Ketone/Alcohol \\
\hline & 15 & 4.5 \\
5 & 26 & 4.0 \\
10 & 30 & 3.5 \\
15 & 32 & 3.1 \\
30 & & \\
\hline a. Cyclododecane (5 mmol) was dissolved in a solution of $\mathrm{FeCl}_{3} .6 \mathrm{H}_{2} \mathrm{O}(0.2$ mmoi), \\
picolinic acid $(0.6$ mmol), and acetic acid (or acetic anhydride, variable amouns) \\
in pyridine $(28.0$ ml). The reaction was initiated by the addition of the required \\
amount of $\mathrm{H}_{2} \mathrm{O}$ and $\mathrm{H}_{2} \mathrm{O}_{2}$. \\
\hline
\end{tabular}

Table 8.

Effect of thiophenol in the $\mathrm{Gif}^{\mathrm{VI}}$ system [cyclododecane ( $5 \mathrm{mmol}$ ) as substrate]

\begin{tabular}{ccc}
\hline $\begin{array}{c}\text { PhSH } \\
(\mathrm{mmol})\end{array}$ & $\begin{array}{c}\text { Conversion } \\
(\%)\end{array}$ & ketone/alcohol \\
\hline 0 & 30.1 & 12.1 \\
1.0 & 29.8 & 3.08 \\
2.0 & 26.0 & 1.40 \\
4.0 & 21.2 & 0.95 \\
\hline
\end{tabular}

We have recently summarised the data in terms of the working hypothesis ${ }^{22}$ shown in Table 9. As we have always argued, intermediate A contains an iron-carbon sigma bond formed by an insertion process of the $\mathrm{Fe}^{\mathrm{V}}$ oxenoid species into the carbon-hydrogen bond. A related insertion process into the sigma carbon-iron bond of (say) diphenyl diselenide affords the phenylseleno derivatives. In Table 9 the second intermediate $\mathbf{B}$ is regarded as an alkoxy-iron species. This would explain the water effect. For the effect of thiophenol and of dianisyl telluride on the ketone-alcohol ratio we supposed that the second oxidation step needed for ketone formation involved a second oxidation of $\mathbf{B}$ brought about through an $\mathrm{Fe}^{\mathrm{III}}$ peroxide species going to $\mathrm{Fe}^{\mathrm{V}}$ oxenoid and reacting as in Table 9 . The reducing agents would then be intercepting the second $\mathrm{Fe}^{\mathrm{II}}$ peroxide species and the ketone would be formed by hydrolysis of an $\mathrm{Fe}^{\mathrm{III}}$ ketal species.

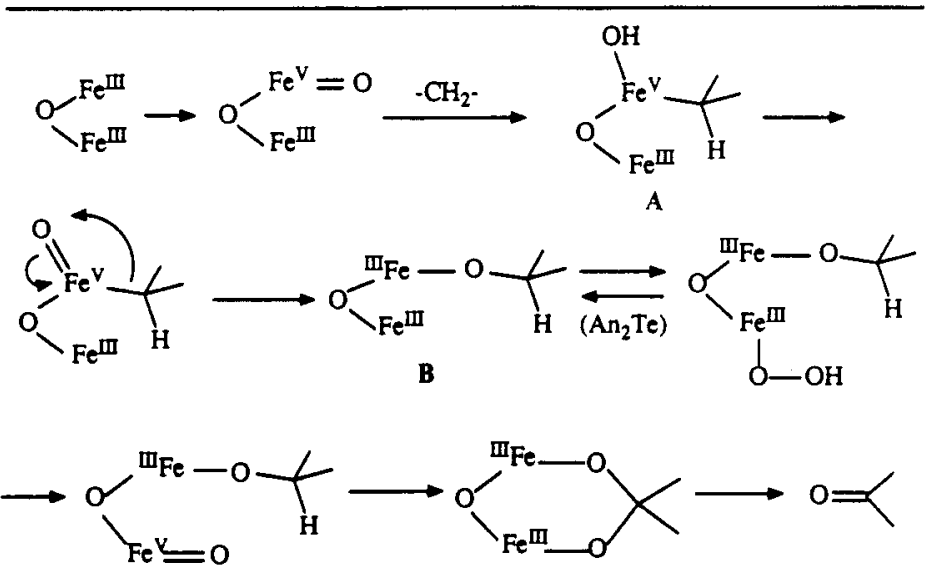

This improved working hypothesis (Table 9) explains all the facts known to us until June 1990. It encouraged us to look for intermediates $\mathbf{A}$ and B. In fact $\mathbf{B}$ is not an alkoxy derivative of $\mathrm{Fe}^{\mathrm{III}}$ and there is a third intermediate $\mathbf{C}$ which is the direct precursor of the ketone (and most of the alcohol with reducing agents like thiophenol). We were, of course, well aware of the difficulties associated with the presence of paramagnetic iron species in proton NMR spectroscopy. However, we thougth that meaningful results might be obtainable using ${ }^{13} \mathrm{C}$ NMR spectroscopy especially using isotopically enriched molecules. Part II describes the identification of intermediate $\mathbf{C}$, in the case of cyclohexane, as cyclohexyl hydroperoxide. 


\section{PART II. DARIO DOLLER}

Preliminary experiments following the course of the GoAggI oxidation of cyclohexane by ${ }^{13} \mathrm{C}$ NMR spectroscopy showed the convenience of using a ${ }^{13} \mathrm{C}$-enriched substrate in order to improve the signal-to-noise ratio and increase the sensitivity of the experiment. Also, picolinic acid was not added to the reaction mixture to allow a reaction rate compatible with the NMR time scale.

Figure 1 shows the series of ${ }^{13} \mathrm{C}-\mathrm{NMR}$ spectra obtained upon addition of hydrogen peroxide $\left(30 \%\right.$ in water) to a solution of $\left[1-{ }^{13} \mathrm{C}\right]$-cyclohexane in deuteropyridine-acetic acid containing a catalytic amount of ferric chloride. The time between consecutive spectra is about twenty minutes. The formation of an intermediate characterized by four peaks at $82.64,30.99,26.23$, and $24.11 \mathrm{ppm}$ can be seen. The intensity of these four signals increases steadily with time, reaching a maximum value at $c a .3 .5$ hours after the addition of hydrogen peroxide. The gradual disappearance of these four peaks is accompanied by the appearance of four new signals at 212.16, 42.00,27.25, and $25.01 \mathrm{ppm}$ assigned to C-1 to 4 of ${ }^{13} \mathrm{C}$-labelled cyclohexanone, respectively ${ }^{23}$.

The possibility of the intermediate being a self-assembled iron(III) cyclohexanolate ${ }^{24}$ was eliminated after recording the ${ }^{13} \mathrm{C}$-NMR spectrum of cyclohexanol in a deuteropyridine-acetic acid-ferric chloride solution. The chemical shifts values obtained for C-1 to C-4 $(69.87,36.61,25.02$, and 26.43 , respectively) did not agree with those obtained for the intermediate.

We then considered the possibility of cyclohexyl hydroperoxide being the intermediate. An authentic sample was prepared ${ }^{25}$ and its ${ }^{13} \mathrm{C}-\mathrm{NMR}$ spectrum recorded. The four observed resonances $(82.72,31.32,26.55$, and $24.38 \mathrm{ppm})$ are in excellent agreement with those found in the kinetic experiment. Thus, the intermediate was characterized as cyclohexyl hydroperoxide. In Figure 2 the peak intensity for the C-2 resonances of the hydroperoxide and the ketone are compared as a function of the reaction time. It can be concluded that cyclohexyl hydroperoxide is the main source of cyclohexanone in the GoAggII oxidation of cyclohexane.

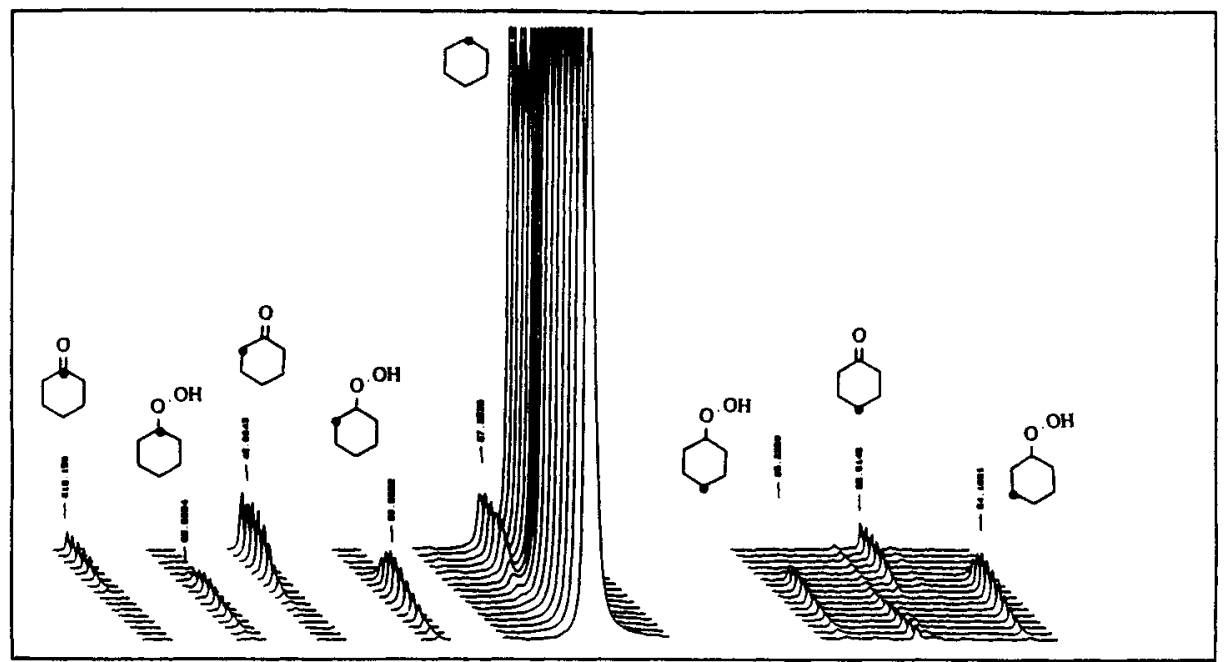

Figure 1

To confirm that the hydroperoxide was an intermediate in the ketonization of methylenic carbons a sample of the cyclohexylhydroperoxide was submitted to GoAgg II conditions (except hydrogen peroxide) and its complete transformation to cyclohexanone was verified, in agreement with previous work ${ }^{26}$. This then leads us to a new working hypothesis (Table 10). Intermediate $A$ reacts with $\mathrm{H}_{2} \mathrm{O}_{2}$, perhaps at first with the more reactive $\mathrm{Fe}^{\mathrm{III}}$ followed by rearrangement (Table 11 ) to give $\mathrm{D}$. By ligand coupling the hydroperoxide $\mathbf{C}$ is formed which then evolves into ketone. The alcohol observed could come via B or it could be formed by ligand coupling from $\mathbf{D}$. The effect of water could be ligand competition on intermediate $\mathbf{D}$ or could be a minor pathway via $\mathbf{B}$ as already discussed. 


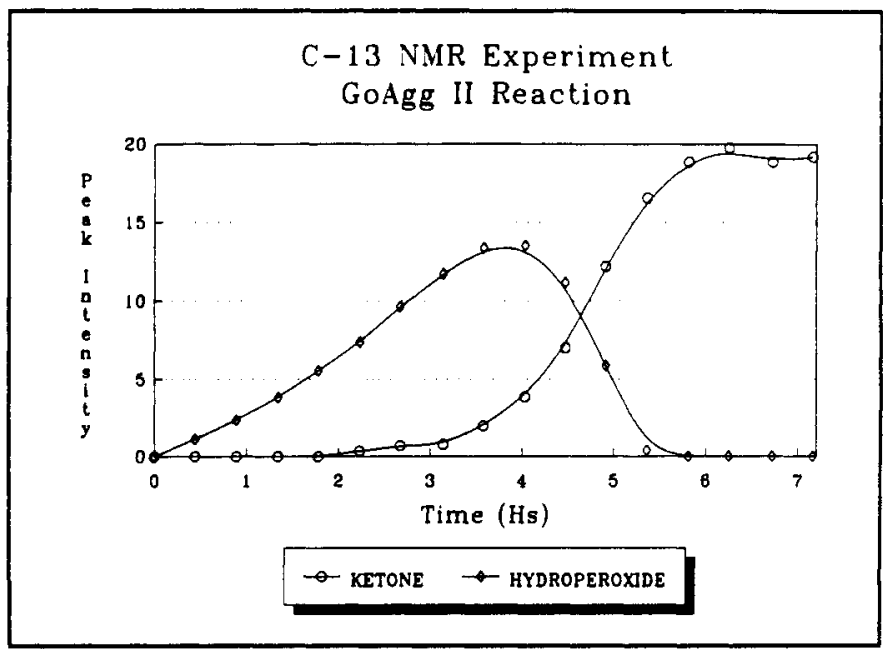

Figure 2

Table 10

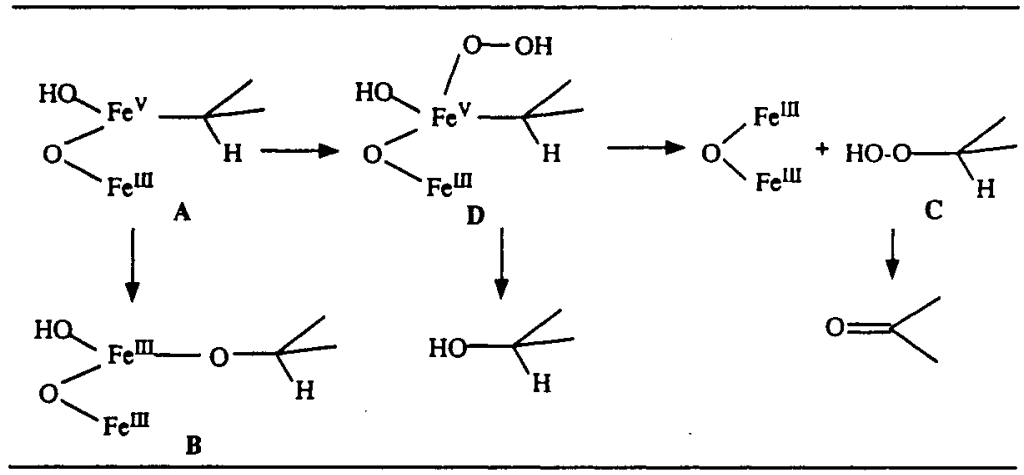

Table 11
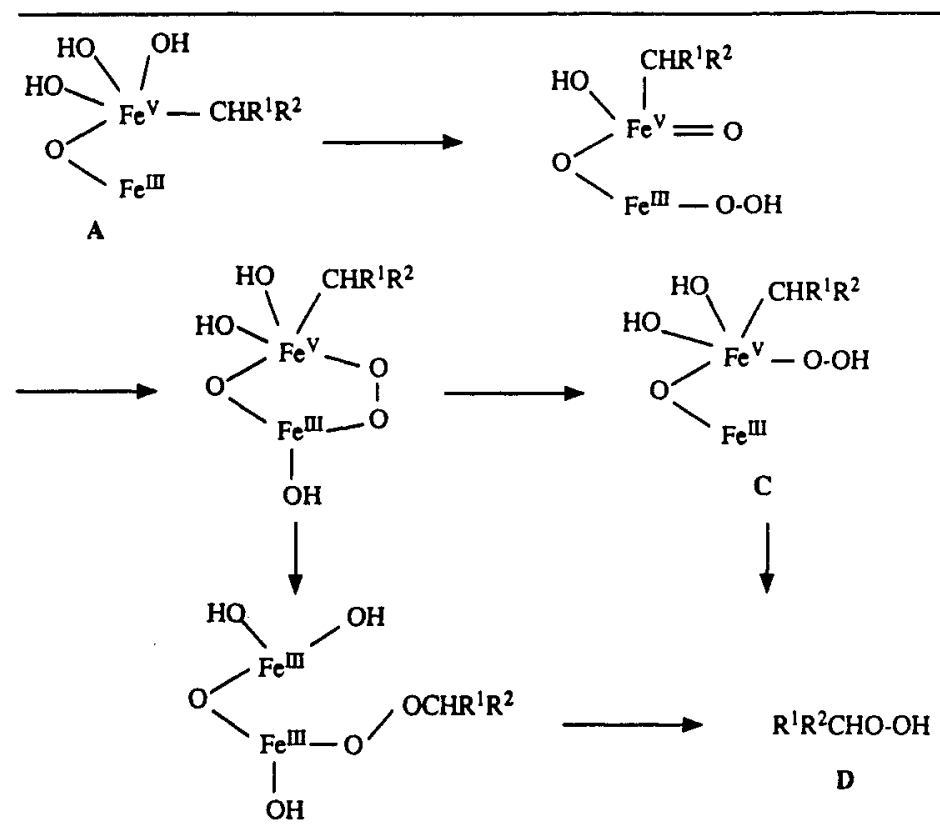
PART III.

The need for the $\mu$-oxo-di-iron dimer is reasonable and is certainly needed to explain $\mathrm{Gif}^{\mathrm{III}}, \mathrm{Gif}^{\mathrm{IV}}$ and other superoxide based systems (Table 12).

Table 12

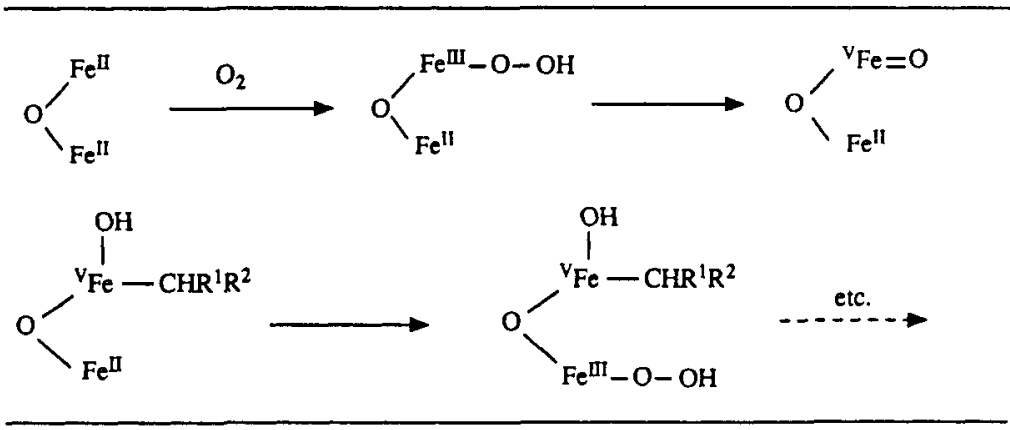

The oxygen-ferrous dipicolinate system of Professor Sawyer ${ }^{9}$ can be explained as in Table 13. Here we follow the proposed ${ }^{9}$ addition of triplet oxygen to give a cyclic di-Fe ${ }^{\text {III }}$ peroxide. Evolution to the usual $\mathrm{Fe}^{\mathrm{V}}$ oxenoid species and hydrocarbon insertion present no difficulties. However, one is obliged to add a hydrogen peroxide transfer process between two di-iron systems to reach the correct oxidation level.

Table 13

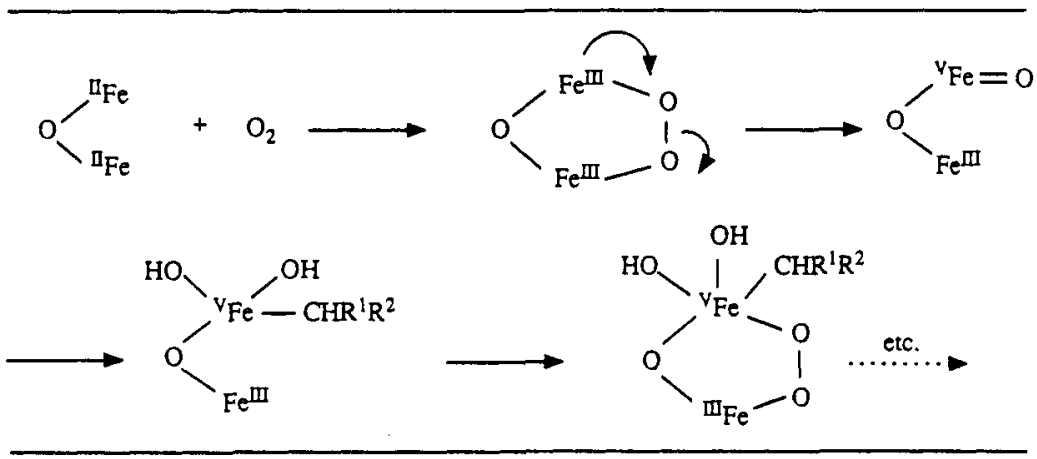

Finally (Table 14) we point out that a complex with $\mathrm{Fe}^{\mathrm{V}}$ and $\mathrm{Fe}^{\mathrm{III}}$ can be regarded as a di-Fe ${ }^{\mathrm{IV}}$ species and also supposed to insert into the $\mathrm{C}-\mathrm{H}$ bond. However, the electrons have finally to be redistributed so that the ligand coupling to hydroperoxide takes place at the $\mathrm{Fe}^{\mathrm{V}} \rightarrow \mathrm{Fe}^{\mathrm{III}}$ level. We consider this as more favourable than the conceptually possible $\mathrm{Fe}^{\mathrm{IV}} \rightarrow \mathrm{Fe}^{\mathrm{II}}$.

Table 14

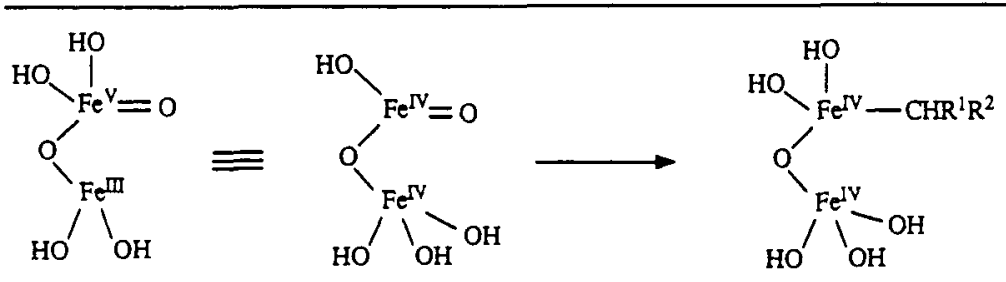<smiles>[R12]C[Y7](O)(O)O[Te](O)(O)OO</smiles>

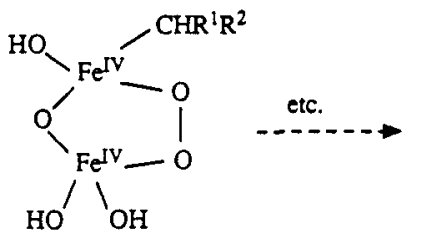




\section{PART IV}

Methane monooxygenase (MMO) is a remarkably interesting enzyme. Thanks especially to the work of Dalton ${ }^{27,28}$, the enzyme has been obtained in a soluble form and characterised as a three component enzyme. The component responsible for the chemical oxidation of methane is a non-porphyrinic molecule containing a $\mu$-oxo di-iron center ${ }^{29}$.

Recent work by Dalton and his collaborators ${ }^{30}$ has shown that MMO is an unusually catholic enzyme, which oxidises many hydrocarbons much larger than methane. The selectivity of an enzyme is usually a reflection of the protein associated with the active center. MMO seems to be different as it tends to give secondary alcohols ${ }^{4}$ and attacks cyclic olefins at the allylic positions with or without a shift of the double bond. This is exactly what is seen in Gif type oxidation and has been interpreted as the participation of a $\pi$-allyl iron complex ${ }^{31}$. Finally, MMO oxidises adamantane with exactly the same selectivity for the secondary and tertiary positions as seen in all the Gif type systems ${ }^{32}$. It will be very interesting to see if methyl hydroperoxide is an intermediate in methane oxidation or not. Since the medium is water, alcohol formation may well be determined by ligand coupling in intermediate D. Alternatively the enzyme could be making methanol via intermediate B. The reducing function of the enzyme could, however, also allow for methyl hydroperoxide to be reduced to methanol.

Similar considerations apply to the important enzyme prolylhydroxylase, which converts peptide bound proline to the genetically uncoded trans-4-hydroxyprolyl residue ${ }^{33}$.

\section{PART V}

Gif type chemistry clearly has potential economic utility. Extensive development work has not been carried out, although the careful and precise work of Schuchardt and his collaborators $^{34}$ has shown how well cyclohexane is oxidised to cyclohexanone. The new Gif type system of Prof. Sawyer has been mentioned above9. His work on the selective ketonisation of saturated hydrocarbons shows the usual Gif type selectivity ${ }^{12}$. Complexing with picolinic acid is good support for the $\mu$-oxo dimer of iron as the basis for Gif type reactivity. Another important article ${ }^{35}$ shows that when an excess of $\mathrm{Fe}^{I I}$ complex is used under GoAgg ${ }^{\text {III }}$ conditions, normal Fenton chemistry is indeed seen. The hydroxyl radicals attack the substrate cyclohexane to give cyclohexyl radicals which are trapped by pyridine or, if diphenyl diselenide is present, by this reagent. When all the diphenyl diselenide has been consumed then the standard $\mathrm{GoAgg}^{\mathrm{II}}$ reaction is seen producing ketone.

Acknowledgements We thank all past and present collaborators for enthousiastic efforts they have devoted to unravelling the mysteries of Gif chemistry. The present group, excluding the authors of this article, are S. Beviere, W. Chavasiri, E. Csuhai, Y. Geletii, H.-J. Lim, W. Liu, C. Saluzzo, T. J. Weiss and L. Zhang. We also thank the organisms that have supported this work, including the N.S.F., the N.I.H., Merck Sharpe and Dohme and Quest Internatl.

\section{REFERENCES}

1. Inter alia A. E. Shilov, 'Activation of Saturated Hydrocarbons by Transition Metal Complexes' D. Reidel Publishing Co., Dordrecht, 1984. R. H. Crabtree , Chem. Rev. 1985, 85, 245. B. Meunier, Bull. Soc. Chim. Fr. 1986, 576. 'Activation and Functionalisation of Alkanes' Ed. C. L. Hill, J. Wiley and Sons, New York, 1989. M. B. Sponsler, B. H. Weiller, P. O. Stoutland, R. G. Bergman, J. Am. Chem. Soc. 1989, 111,6841 , and references there cited.

2. T. J. Mc Murry, J. T. Groves in 'Cytochrome $P_{450}$. Structure, Mechanism and Biochemistry'. Ed. P. Ortiz de Montellano, Plenum Press, New York, 1985, Chap. 1. D. Mansuy, Pure and Appl. Chem. 1987, 59, 759. 
3. J. P. Collman, X. Zhang, R. T. Hembre, J. J. Braumann, J. Am. Chem. Soc. 1990, 112, 5357. J. P. Collman, P. D. Hampton, J. J. Braumann, ibid. 1990, 112, 2977, 2986, and references there cited.

4. C. Walling. Acc. Chem. Res. 1975, 8, 125.

5. I. Tabushi, T. Nakajima and K. Seto, Tetrahedron Lett. 1980, 21, 2565.

6. D. H. R. Barton, M. J. Gastiger, W. B. Motherwell. J. Chem. Soc., Chem. Commun. 1983, 41.

7. Idem, Ibid, 1983, 731.

8. D. H. R. Barton, F. Halley, N. Ozbalik, E. Young, G. Balavoine, A Gref, J. Boivin. New J. Chem. 1989, 13, 177.

9. C. Sheu, A. Sobkowiak, S. Jeon, D. T. Sawyer. J. Am. Chem. Soc. 1990, 112, 879.

10. Y. V. Geletii, V. V. Lavrushko, G. V. Lubimova. J. Chem. Soc., Chem. Commun. 1988, 936.

11. G. Balavoine, D. H. R. Barton, J. Boivin, A. Gref. Tetrahedron Lett. 1990, 31, 659.

12. See C. Sheu, S. A. Richert, P. Cofré, B. Ross, A. Sobkowiak, D. T. Sawyer, J. R. Kanofsky. J Am. Chem. Soc. 1990, 112, 1936.

13. E. About-Jaudet, D. H. R. Barton, E. Csuhai, N. Ozbalik. Tetrahedron Lett. 1990, 31 , 1657.

14. G. Balavoine, D. H. R. Barton, A. Gref, I. Lellouche. Tetrahedron Lett. 1990, in press.

15. D. H. R. Barton, F. Halley, N. Ozbalik, M. Schmitt, E. Young, G. Balavoine. J. Am. Chem. Soc. 1989, 111, 7144.

16. D. H. R. Barton, E. Csuhai, D. Doller, N. Ozbalik, N. Senglet. Tetrahedron Lett. 1990, 31, 3097.

17. D. H. R. Barton, E. Csuhai, D. Doller. In preparation.

18. D. H. R. Barton, E. Csuhai, N. Ozbalik. Tetrahedron 1990, 46, 3743.

19. G. Balavoine, D. H. R. Barton, J. Boivin, P. LeCoupanec, P. Lelandais. New J. Chem. 1989, 13, 691 .

20. D. H. R. Barton, E. Csuhai, D. Doller. In preparation.

21. J. A. Franz, B. A. Bushaw, M. S. Alnajiar. J. Am. Chem. Soc. 1989, 111, 268.

22. D. H. R. Barton, E. Csuhai, N. Ozbalik. Tetrahedron Lett. 1990, 31, 2817. D. H. R. Barton, Ė. Csuhai, D. Doller, N. Ozbalik, G. Balavoine. Proc. Natl. Acad. Sci. 1990 , 87,3401 .

23. E. Pretsch, J. Seibl, W. Simon, T. Clerc. 'Spectral Data for Structure Determination of Organic Compounds'. Springer-Verlag, Berlin, 1983.

24. S. M. Gorun, G. C. Papaefthymiou, R. B. Frankel, S. J. Lippard. J. Am. Chem. Soc. 1987, 109, 3337. R. W. Saalfrank, A. Stark, M. Bremer, H. U. Hummel. Angew. Chem. Int. Ed. Engl. 1990, 29, 311.

25. H. R. Williams, H. S. Mosher. J. Am. Chem. Soc. 1954, 76, 2984, 2987.

26. D. H. R. Barton, E. Csuhai, unpublished observations.

27. H. Dalton. Adv. Appl. Microbiol. 1980, 26, 71.

28. J. Colby, H. Dalton. Biochem. J. 1978, 171, 461:

29. R. C. Prince, G. N. Geoge, J. C. Savas, S. P. Cramer, R. N. Patel. Biochim. Biophys. Acta 1988, 952, 220. A. Ericson, B. Hedman, K. O. Hodgson, J. Green, H. Dalton, J. G. Bentsen, R. H. Beer, Lippard, S. J. J. Am. Chem. Soc. 1988, 110, 2330. B. G. Fox, K. K. Sureus, E. Münck, J. D. Lipscomb. J. Biol. Chem. 1988, 263, 10553.

30. J. Green, H. Dalton. J. Biol. Chem. 1989, 264, 17698. D. J. Leak, H. Dalton. Biocatalysis 1987, 1, 23.

31. D. H. R. Barton, K. W. Lee, W. Mehl, N. Ozbalik, L. Zhang. Tetrahedron 1990, 46, 3753.

32. D. H. R. Barton, È. Csuhai, D. Doller, N. Ozbalik, G. Balavoine. Proc. Natl. Acad. Sci. 1990, 87, 3401 .

33. H. M. Hanauske-Abel, V. Günzler. J. Theor. Biol. 1982, 94, 421.

34. U. Schuchardt, V. Mano. Preprints First World Congress and Second European Workshop on New Developments in Selective Oxidation, 1989, D6, 01. U. Schuchardt, E. V. Spinace, V. Mano. $4^{\text {th }}$ International Symposium on Activation of Dioxygen and Homogeneous Catalytic Oxidation, Balatonfüred, Hungary, 1990.

35. C. Sheu, A. Sobkowiak, L. Zhang, N. Ozbalik, D. H. R. Barton, D. T. Sawyer. J. Am. Chem. Soc. 1989, 112, 879. 